\title{
Microfinance for poverty alleviation: Do transnational initiatives overlook fundamental questions of competition and intermediation?
}

\author{
Frithjof Arp, Alvin Ardisa and Alviani Ardisa*
}

Numerous microfinance initiatives around the world aim to alleviate poverty in developing countries. However, debate persists about their effectiveness and sustainability - a concern for transnational corporations and the international business community, which contribute about $\$ 9.4$ billion to microfinance funding. In this policy-oriented article we aggregate findings from two studies in Indonesia that help explain why moneylending can still thrive when low-interest microfinance is widely available and why the poorest borrowers benefit less than the less-poor. To avoid methodological debates about validity, we interview market participants and triangulate the perspectives of borrowers with those of formal and informal lenders. Importantly, our research includes current and past borrowing from formal and informal sources, prompting participants to draw comparisons. We find that the importance to borrowers of key characteristics of informal lending is insufficiently recognized and that inappropriate human resource management and informal intermediation are significant problems. The latter can be an unintended consequence of formal microfinance: The availability of formal low-interest microfinance creates informal intermediation opportunities for entrepreneurs, often developing from casual intermediation into systematic deception. We discuss implications for microfinance policy with reference to the United Nations Sustainable Development Goals and offer suggestions for further research.

Key words: microfinance, competition, formal, informal, intermediation, Indonesia, qualitative

\footnotetext{
* The authors are at the Department of International Business \& Management, the University of Nottingham, Ningbo, China. The corresponding author is Frithjof Arp. Contact: frithjof.arp@nottingham. edu.cn The authors are grateful for comments from participants of the first international 'Workshop on Human Security in the Global South', 24-25 February 2016 at the University of Nottingham, Ningbo, China, and of the 2016 meeting of the Academy of International Business, 27-30 June 2016, New Orleans, United States.
} 


\section{Introduction}

Debate persists about the effectiveness and sustainability of international microfinance initiatives to alleviate poverty (Chliova, Brinckmann and Rosenbusch, 2015; Khavul, Chavez and Bruton, 2013). Data and statistical methods are questioned (see e.g. the 15-years-and-ongoing dispute in Pitt, 2014; Pitt and Khandker, 1998; Roodman and Morduch, 2014), and some studies even suggest a lack of any significant effect (Nghiem, Coelli and Rao, 2012). Other studies find that microfinance is effective but that the poorest borrowers benefit less than less-poor borrowers (Islam, Nguyen and Smyth, 2015), particularly when longer time periods are taken into account (Banerjee, Breza, Duflo and Kinnan, 2015). Hence, our understanding of the effects of microfinance remains incomplete.

Why, for example, can moneylenders still thrive in countries where low-interest microfinance is widely available? Many studies of international microfinance appear to occur in a vacuum, assess the effectiveness of specific initiatives in isolation and ignore competition from informal sources of lending or other phenomena not easily quantified (Arp and Ardisa, 2016a). There are "important gaps in data availability, especially in developing countries, as well as for informal and rural sectors" (United Nations Inter-agency Task Force on Financing for Development, 2016: 20). But if formal microfinance were effective, one would expect an obvious impact on its informal competitors. Competition theory suggests that products or services with inherent advantages for customers will expand their share of competitive markets and potentially even achieve monopoly status (Sharkey, 1982). Formal, low-interest microfinance offers inherent advantages to poor borrowers, who often start their microventures through credit from informal lenders (Banerjee et al., 2015; Tsai, 2004; Turvey and Kong, 2010). Hence, low-interest, formal microfinance could be expected to achieve monopoly status. At the very least, the effectiveness of formal microcredit should be noticeable - if not precisely enumerable - from its impact on informal competitors.

Monopolistic competition theory (Chamberlin, 1947) describes imperfect markets in which competitors coexist without impact on each other. This is undesirable, as inefficient markets create social costs that burden the international community: Lenders can charge prices exceeding marginal costs, operate with excess capacity and spend too much on publicity rather than reduce the price of their product (see e.g. Krugman, Obstfeld and Melitz, 2015). This risk of social burden leads us to a discussion of microfinance policy and suggestions for future research with reference to the first and foremost United Nations (UN) Sustainable Development Goal (SDG) of ending poverty "in all its forms everywhere" (United Nations, 2017) as well as more specific considerations (United Nations IATF on Financing for Development, 2016). In the next section, a review of the literature and a summary of our research project to date provide the basis for that discussion. 


\section{Literature review}

Microfinance initiatives for low-income households are deemed by many to have a positive effect on the lives of people in poor countries (Baye, 2013; Ghalib, Malki and Imai, 2015; Imai, Arun and Annim, 2010; Imai et al., 2012; Imai and Azam, 2012). Not only taxpayer-funded donations support these initiatives; in addition, transnational corporations (TNCs) and the international business community are deeply involved. The food giant Mars, for example, supports microfinance initiatives in 15 cocoagrowing communities in countries such as Côte d'Ivoire and Indonesia. Seeking to empower female entrepreneurs, it provides loans and microgrants to fund inputs within its supply chain (Mars, 2015). The banking giant Citibank invests in microfinance initiatives through a range of programmes. It maintains a partnership with the U.S. Government's Overseas Private Investment Corporation, which funds microfinance initiatives in developing markets around the world and has provided more than US\$417.4 million in financing to 46 microfinance institutions in 24 countries. It also partners with the Philippines-based Asian Development Bank (ADB) to facilitate local currency loans of up to US\$100 million to microfinance institutions in the Asia Pacific region (Citibank, 2016: 80). TNCs Pearson, Hewlett-Packard, Google and MetLife are among the funding partners of the transnational initiative Kiva, which provides US\$979.9 million in microfinancing for poverty alleviation in 83 countries (Kiva.org, 2016). Indeed, the World Bank's 2016 Cross-Border Funder Survey estimates that US\$9.4 billion (28\%) of the US\$34 billion of funding for financial inclusion comes from private sources, with more than two thirds of overall funding used to finance lending portfolios (Soursourian, Dashi and Dokle, 2016). Hence, TNCs and the international business community are important stakeholders in the debate about microfinance effectiveness.

There appears to be a growing consensus that poverty alleviation requires asset accumulation through entrepreneurial activities (Swain, Nguyen and Vo, 2008). Loans to micro-entrepreneurs help people accumulate assets, whereas non-productive loans merely help people consume more (Banerjee et al., 2015; Bruton, Ketchen and Ireland, 2013; Usman et al., 2015). Therefore, research typically focuses on micro-entrepreneurs (Bruton, Khavul and Chavez, 2011), and we follow this agenda.

For micro-entrepreneurs in poor regions, informal as well as formal microfinance plays an important role (Banerjee et al., 2015). In China, for example, more than $67 \%$ of farm households borrow from friends and relatives (Turvey and Kong, 2010), as these informal lenders are accessible "at no cost" (Gine, 2011) other than maintaining a social network (Banerjee et al., 2015). Other sources of informal credit are moneylenders, trade credit, and rotating savings and credit associations (ROSCAs; see e.g. Tsai, 2004). For example, ROSCAs are seen as increasing venture opportunities, especially for women, even in less-poor regions such as urban Malaysia (Ghazali, 2003). 
In addition, loan officers in formal microfinance organizations play an important role. In Zambia, for example, they are found to act more like "debt collectors" although they were originally recruited to empower the poor (Siwale and Ritchie, 2012). In Nigeria, complex application processes and loan officers demanding collateral lead to informal over formal borrowing, and the majority of micro-entrepreneurs in a study of Western Kenya choose informal lenders for the same reasons (Alila, 1998). Many micro-entrepreneurs start their ventures using informal microcredit without collateral and with little or no documentation. Informal lenders provide access to convenient and quickly disbursed loans, are available at any time of day and night, blend with the community, know borrowers at a personal level and cater to specific needs of rural residents (Jones, 2008).

Unfortunately, informal lending also involves loan sharks charging high interest rates and collecting debt through coercive methods. Many studies identify the limited supply of formal credit as the reason for their persistence (e.g. Tsai, 2004). However, the continued existence of informal lending cannot anymore be explained everywhere by a gap between supply and demand. Formal microcredit has become widely available in many countries, and multiple operational problems have been addressed (the cost of processing many small loans, lack of borrower credit histories, lack of collateral and income seasonality of many ventures). Both monitoring and transaction costs, for example, can be reduced by gleaning information from social networks of local communities (Khavul et al., 2013). Therefore, the question remains why informal lending still thrives when formal microfinance is widely available. We explore that question with the following methods.

\section{Methods}

Roodman and Morduch (2014: 599) warn that exclusive reliance on one type of microfinance study "is not optimal" because validity can be problematic and results can disappear after dropping statistical outliers and assumptions critical for the analysis. They argue that researchers, reviewers and journal editors should "take steps to prevent methodological complexity from obscuring fundamental issues" (Roodman and Morduch, 2014: 601). In our research, we avoid methodological complexity through an inductive approach (Corbin and Strauss, 2008). Assessing the effectiveness of microfinance through its effect on competitors, we interview market participants and triangulate the perspectives of borrowers with those of formal and informal lenders. Importantly, this includes current and past borrowing from formal and informal sources, prompting participants to draw comparisons.

Our choice of Indonesia as the research setting is justified by that country often being held up, along with Bangladesh, as an example of widely available microfinance. 
Indonesia has more than 7,000 microfinance outlets offering low interest rates, loans not requiring collateral and repayment options that account for income seasonality (Bank Rakyat Indonesia, 2015). They are supported by the Government through Bank Rakyat Indonesia (BRI), an arrangement which, according to UNESCO's and its own assessment, has proved to be successful, sustainable and profitable (Bank Rakyat Indonesia, 2015a; Robinson, 1997). The international business community and TNCs hold significant stakes in the effectiveness of microfinance initiatives in Indonesia: Citibank, Mars and Kiva.org, for example, are active. The insurance giant Allianz, through a public-private partnership with the German development organization GIZ and Indonesian microfinance outlets, developed a modular creditinsurance product (payung keluarga: family umbrella) with an average premium of US\$1.30 per year that has reached the milestone of one million active insured people. Crucially, it is local loan officers that decide which modules to apply, and the chosen package is compulsory for microfinance borrowers (Prasetyo, 2013).

Aiming to answer "why" questions, we chose semi-structured interviews to gain in-depth insight into the phenomena under investigation, establish meaning and construct theories based on the data collected. Rigidly structured interviews or quantitative methods such as surveys would not permit unknown themes to surface (Creswell, 2007). We conducted interviews in suburban Yogyakarta and its surrounding rural areas from 6 June to 5 July 2015 and from 14 June to 20 July 2016. Our fieldwork in 2015 on competition between formal and informal lending (Arp and Ardisa, 2016a, 2016b) included the observation of informal intermediation. Therefore, we returned in 2016 to further explore this phenomenon. We conducted interviews with 47 participants, of whom 24 are borrowers (farmers, cottage industry and smallstore operators), 5 are representatives of formal microfinance organizations and 18 are a purposive sample of informal intermediaries. Access to participants was difficult but was gained through one interviewee in 2015 and further personal approaches in 2016. This was combined with the snowball method of asking initial participants (borrowers and intermediaries) for additional introductions.

The approach worked well with borrowers and informal intermediaries once trust had been built, but not so well for representatives of formal microfinance initiatives once they understood that we wanted to discuss the topic of informal intermediation. Eleven informal intermediaries borrow from BRI outlets and three from Bank Pembangunan Daerah (BPD), Bank Perkreditan Rakyat (BPR), and a formal cooperative (Koperasi). Their loans are obtained through the governmentsupported, low-interest, collateral-free Kredit Usaha Rakyat (KUR) programme (loan amounts Rp 1-25 million) or commercial programmes that offer loan amounts up to Rp 200 million. The Government allocated Rp 10.5 trillion to subsidize the low interest rate, expand access to cheap loans and motivate entrepreneurship (Bank Rakyat Indonesia, 2016). 
We were concerned, perhaps excessively, about the sensitivity of the informal intermediation topic. Our strategy therefore was to have the 2016 interviews conducted by a youngish, innocent-and-naïvely-interested-looking researcher (we do not mean to suggest that age or looks are cognate with naïvety). This strategy is based on the notion that the appearance of researcher naïvety can help make interviewees feel secure and comfortable to volunteer information (Davidson, 2003). Specifically, this strategy helped "encourage participants to elaborate spontaneously on their own answers in fleshing out the details of their story" (Davidson, 2003: 82). To further enhance the "no risk" impression, all interview questions were asked in standard Bahasa Indonesia typical for a naïve, young, big-city academic from Jakarta. Some participants responded in Bahasa Indonesia and some in Javanese.

Data were analysed with the aid of a second coder and spreadsheets containing participant numbers and texts. We first coded the transcribed interview segments for the key themes that had emerged early and then categorized subthemes. We then held discussions to establish a common understanding of difficult-to-translate interview segments, the meaning intended by participants, which first-tier themes the various subthemes belong to and the relative importance of themes. The rudimentary knowledge of Indonesian of the second coder helped in that regard. We had to, for example, consider the conceptual equivalence of "to give money" and "to lend money" in some of the interview terminology, and discuss the most appropriate translation of Indonesian terms such as bank besar and bank bulanan (literally: big bank and monthly bank, indicating the interest payment frequency of formal microfinance), versus lintah darat and rentenir (leech or blood sucker and loan shark), and pedagang, pengepul and tengkulak (trader, collector or hoarder, and middleman).

\section{Findings}

We found that poor human resource management and informal intermediation diminish the effectiveness of formal microfinance. In addition, key characteristics of some informal lending are insufficiently recognized. Our 2015 study found two distinct types of informal microcredit competing successfully with formal microfinance organizations: moneylenders and trader-financiers (Arp and Ardisa, 2016b). We also found in 2015 that borrowers referred to some informal lenders as tengkulak (middlemen). This caused us to collect additional data in 2016 showing that many moneylenders intermediate between formal microfinance organizations and microentrepreneurs by splitting loans obtained from formal microfinance into smaller credits to extend to borrowers. In aggregate, our findings help explain why the poorest borrowers benefit less from formal microfinance than do less-poor borrowers. 


\subsection{Why moneylending can still thrive}

Our findings on this aspect are congruent with other studies. All interviewees who borrow from moneylenders view the ease of obtaining loans as the greatest advantage of this source of funding. The need for formal microfinance initiatives to improve ease of access is emphasized by our finding that some micro-entrepreneurs who borrowed from formal microfinance in the past have returned to moneylenders. They report being angry about having to close their store, queue at crowded microfinance offices and provide documentation such as land or birth certificates. Some of the poorest in Indonesia have neither birth certificates nor any other form of official documents. Moneylenders offer small, short-term loans without documentation that are available quickly, e.g. when borrowers suddenly need to order stock from distant cities.

More important, borrowers complain that loan officers at formal microfinance organizations ask for collateral despite the Government advertising collateral-free microfinance (KUR). Moneylenders take advantage of the fact that human resource management practices at formal microfinance organizations incentivize loan officers to achieve low ratios of non-performing loans (NPLS) rather than to extend credit to the right borrowers. A typical remark of a moneylender:

I know that [this formal lender] gives loans up to [Rp] 20 million without collateral, yes I know it. Actually, if [my borrower] is offered a loan without collateral from a bank, she will want it. But the constraints are the procedures.

The procedures discourage poor borrowers in multiple ways. What borrowers need are small, collateral-free loans without documentation and bureaucratic procedures, quickly disbursed, and available as and when business opportunities arise:

I will receive the money right away. I like it fast because, for business, once I get the loan, I can quickly start earning!

Borrowers perceive the short loan periods and small loans of moneylenders as "finishing" loans faster in order to borrow anew. They fear not being able to make large monthly payments to formal microfinance organizations, perceived as "more expensive" than the "cheaper" small daily payments to moneylenders. More financially literate borrowers see the high cost of daily payments but, owing to demands for collateral from loan officers, see no alternative to moneylenders. Daily payments are particularly problematic for cottage industry operators who can collect revenue only after production processes are completed. Their lack of daily cash flow mirrors the income seasonality of poor farmers in rural areas and helps explain the existence of the second form of informal lending we found. 


\subsection{Why trade finance can successfully compete with formal microfinance}

Trader-financiers provide microcredit, collaborate closely with borrowers, and connect producers and markets. Among their clients we again found entrepreneurs who had previously borrowed from formal microfinance. Comparisons drawn by these interviewees emphasize the need for formal microfinance organizations to improve their competitive offers.

Microcredit from trader-financiers typically takes the form of productive goods rather than cash. For example, trader-financiers supply seeds, tools, plastic sheets, fertilizers or pesticides that are valued so that borrowers owe fixed amounts. Loan amounts are often significantly larger than those from moneylenders, and borrowers are obliged to repay by selling their outputs to trader-financiers below the market prices in the surrounding areas. Trader-financiers distribute outputs to urban markets where prices (e.g. for fresh produce) are higher than in remote areas. Hence, traderfinanciers generate multiple-source revenue from upstream, downstream and arbitrage opportunities between rural village and distant town markets that borrowers are unable to reach. Another important characteristic is the implicit interest of trade finance, causing many borrowers to not perceive it as lending:

I asked him and he bought me plastics and seeds. I did not borrow any money.

There is no interest rate. There is no interest, unlike loans from neighbours or banks.

In addition, trader-financiers ensure the sale of perishable produce; are extremely flexible with payments, debt rollovers and additional loans, e.g. when crops fail; and provide practical help with harvesting. Although some borrowers recognize that larger loans are available through formal microfinance, they prefer trader-financiers because of their integration in rural communities. For example, substantial trust is involved during the harvesting, transportation and weighing processes, with farmers and trader-financiers trusting each other to weigh produce correctly without both parties present. Borrowers view trader-financiers as genuinely supportive.

\subsection{Why informal intermediation can occur}

Informal intermediation is common. Intermediaries typically borrow small amounts offered through the KUR programme or other poverty alleviation initiatives, and then lend on a fraction or the entire loan to other borrowers ("I read it as an opportunity for additional income"). Thus, the availability of formal, low-interest microfinance creates intermediation opportunities for entrepreneurs, often developing from casual 
intermediation into systematic deception for further loans (professional intermediation). An example of casual deception is when market stall operators apply for unnecessarily large formal loans, claiming to purchase additional inventory not actually needed. Such casual intermediaries lend to poorer borrowers on an opportunistic basis. An example of systematic deception are small repair shops that obtain loans to use for the shop's operation when, in reality, the loans are used for complex arrangements such as providing credits to the poor for the purchase of motor scooters while renting the same motor scooters on a time-share basis to others.

Poor human resource management at formal microfinance organizations permits indeed, even fosters - informal intermediation and diminishes the effectiveness of formal microfinance. We found that loan officers at formal microfinance organizations are incentivized to focus on quantitative outcomes such as low NPL ratios, the number of loans and rollovers of "safe" loans, rather than on the poorest borrowers. Well aware of informal intermediation activities and deceptions, they deliberately ignore this information and extend loans to those borrowers they deem safest. We also found collusion between intermediaries and loan officers, as well as former loan officers becoming moneylending entrepreneurs:

If I had to sell noodles or operate a small grocery store, it would be hard. [...] It's nice to do this kind of business. It is easy to do.

I worked at the Klaten office of a koperasi from 2005 to 2009. Then I realised that I will not make much if I kept working in the koperasi. A. established an additional cooperative in Wonosari, while I and my friends established here, in Klaten and Solo. A. has a license, I don't have license.

The people do not care whether we have licenses or not. What they need is a quick loan.

Some of the businesses owned by intermediaries are genuine while others purely serve as a front to obtain funding from formal microfinance lenders. Different informal intermediation business models can be distinguished, with those at the professional loan shark end of the spectrum benefiting most from the availability of formal microfinance. Some of these businesses conduct complex operations that provide them with multiple revenue streams. Formal lenders do not thoroughly check the businesses of informal intermediaries and disburse loans without regard to poverty alleviation objectives. Intermediaries we interviewed told us that, as long as they pay instalments on time, loan officers do not care what the loans are used for. Provided that informal intermediaries have good credit scores, they can easily obtain additional loans. 


\section{Discussion and implications}

Examining microfinance effectiveness through the impact it has on competitors provides a useful lens, helping to identify weaknesses. Microfinance initiatives may well be successful, profitable and sustainable if examined in isolation, but that does not mean they are effective in alleviating poverty and meeting the UN SDGs. Limited effectiveness would be a concern for both public sector supporters and private sector TNCs, with their US\$9.4 billion stake.

Grounded in the reality of market participants, our findings hold implications for international microfinance practice, policy and further research. The first and foremost UN SDG is to end "poverty in all its forms everywhere" (United Nations, 2017). Within this SDG, the highest priority is given to the eradication of extreme poverty (SDG 1.1), closely followed by "ensuring... access to... financial services, including microfinance" (SDG 1.4). Our findings help explain a lack of sustainable effect on extreme poverty. Prior studies report that the poorest borrowers benefit less from formal microfinance than less-poor borrowers (Islam et al., 2015). Banerjee et al. (2015), taking a period of six years into account, report that this effect persists two years after formal microfinance is withdrawn. Persistent benefits to the poorest entrepreneurs without prior businesses are "generally indistinguishable from zero" (Banerjee et al., 2015). Our finding of informal intermediation helps explain this conundrum. An unintended consequence of formal microfinance can be that it provides informal intermediation opportunities to entrepreneurial individuals, particularly those who have extant businesses or who are able to portray themselves as businesses. The poorest of the poor entrepreneurs benefit less than the less-poor do. Hence, informal intermediation appears to be an important but neglected variable in assessments of the effectiveness of microfinance initiatives. We propose to the international business community to include this variable in large-scale, quantitative assessments of microfinance effectiveness. In aggregate, the propositions suggest that the larger the extent of informal intermediation, the lower the effectiveness of microfinance initiatives to alleviate poverty among the poorest of the poor (Arp, 2017). Although further qualitative research on unintended consequences of formal microfinance seems advisable, the various propositions contribute to the quantitative evaluation toolbox of measurable characteristics.

The UN stresses "the importance of designing regulatory and policy frameworks across all financial intermediation" (United Nations IATF on Financing for Development, 2016: 52). Our research findings on informal intermediation highlight that key characteristics of informal lending are insufficiently recognized. Similarly, our findings about the implicit interest of trade finance, which causes borrowers not to perceive it as lending, deserve the attention of policymakers and comprehensive further research. So do the other services of trader-financiers: The UN recognizes 
that "institutions may require a more qualitative analysis that highlights examples where different financial intermediaries have helped advance the financial inclusion agenda" (ibid, page 58). Our approach illustrates that poverty alleviation requires more than "ensuring access to microfinance" (SDG 1.4) and quantitatively assessing financial effectiveness in isolation. Poor entrepreneurs need operational help: help to be productive (tools, fertilizer, seeds and the like), help with transport and logistics (bringing rural and cottage industry products to distant markets) or help during harvest (when perishable produce quickly spoils). At a minimum, they need help to operate without the disruption of queuing at offices for cumbersome processes.

Our findings of intermediaries' multiple-source revenue models jives with ideas for "microcredit-plus programmes" explored by some TNCs such as Allianz and Mars, to provide practical and social support to clients in addition to capital. Their international microfinance initiatives may benefit from examining closely what trader-financiers do as those individuals live and work in the community, provide operational help and cooperate well with the poorest of the poor (cf. Jones, 2008). Providing logistics, distribution, assured sale of perishable products and price arbitrage between distant markets (perhaps through mutually owned cooperatives) may be starting points for TNCs and the international business community. Addressing other operational needs of the poorest may lead to new forms of microcredit initiatives over time. Some traderfinanciers can perhaps be coopted and their entrepreneurship harnessed. Policies could also formalize, support and lightly regulate existing trader-financier networks in line with UN SDG 8.3 "to integrate the informal sector into the formal economy" (United Nations Inter-agency Task Force on Financing for Development, 2016: 19).

Our findings emphasize that the research agenda must also include human resource management practices. Methods to examine the crucial role of loan officer incentives deserve particular attention as "monitoring capacity for costeffective credit evaluation would require qualitative work" (United Nations Interagency Task Force on Financing for Development, 2016: 58). Collaborative research involving TNCs holds particular promise, as private sector international expertise on incentives and appropriate human resource management may be applicable to domestic government-supported initiatives. The US\$9.4 billion stakeholder role of the international business community demands that TNCs examine the interface between loan officers' incentives for correct evaluation and the types of credit offered. To better compete with moneylenders, formal microfinance initiatives should also offer smaller loans, shorter loan periods, daily or weekly payments, quicker disbursement, simpler procedures and draw-down facilities for multiple, irregular, credit withdrawals (e.g. inventory purchases available at temporarily low prices). We suggest further research, including quantitative and mixed methods, on the effectiveness of each of these characteristics. 
We do not advocate more regulation. In our view, regulations and their enforcement should solely target coercive intermediation practices at the extreme, loan-shark end of the informal lender spectrum. What constitutes usury, for example, has been debated since biblical times at least and will perhaps be debated forever. Instead of targeting usury, we advocate three groups of measures: first, learning from, cooperating with and potentially coopting informal lenders in line with UN SDG 8.3; second, improving human resource management in microfinance organizations and providing appropriate incentives to loan officers; third, ensuring ubiquitous basic financial literacy so that the poorest can evaluate whether operational services provided by informal lenders such as trader-financiers make up for the cost of their loans, which is higher more than that of formal microfinance. Enabling micro-entrepreneurs to make educated decisions about formal versus informal lenders may be as important as ensuring access to multiple microfinance market participants. Financial literacy initiatives could build on the reflexivity and worries of micro-entrepreneurs about self-discipline (Arp and Ardisa, 2016a: 16) and must include those that are otherwise entirely illiterate. We deem insufficient the UN's assessment of financial literacy through student modules in the Gallup Global Financial Literacy Survey (United Nations IATF on Financing for Development, 2016: 59).

\section{Conclusion}

This article's main purpose is to help set an agenda for further research and discussion. It makes two interrelated contributions. First is the identification and characterization of informal microcredit beyond formal lenders that has been examined in prior research (e.g. Bos and Millone, 2015). Clearly, lending is heterogeneous and the competition to formal microfinance does not only comprise usurious moneylending by loan sharks.

The second and main contribution of this article is the identification of informal intermediation as a significant (current) problem but also a potential (future) element of sustainable solutions. Microfinance organizations need fewer inappropriately incentivized loan officers and more entrepreneurial individuals with a trader-financier mindset designing multiple-source revenue models. Our contribution to theory, that the availability of formal low-interest microfinance can create unintended entrepreneurship opportunities (informal intermediation), needs to be considered in research and microfinance practice.

Our research contributes to the understanding of lending to the poorest of poor micro-entrepreneurs through its grounded approach and focus on competitive impact. The debate on microfinance effectiveness has persisted because of a 
lack of focus on the fundamental question of competition. This article deepens understanding of formal microcredit by detailing why moneylending still thrives when low-interest microfinance is widely available. Neither formal microfinance nor research on its effectiveness operates in a competitive vacuum: Other forms of lending (and alternative approaches to research) exist. Learning from other market participants can be useful.

\section{References}

Alila, P. O. (1998). Informal credit and rural small enterprises growth. Journal of Asian and African Studies, 33(2), 159

Arp, F. (2017). Do the world's poverty alleviation initiatives overlook an important variable? Towards a theory on effects of informal intermediation. Refereed Paper, Academy of International Business (AIB) 2017 Conference, 3 July, Dubai, United Arab Emirates.

Arp, F., and Ardisa, A. (2016a). Assessing the effectiveness of microcredit for poverty alleviation: an alternative approach to avoid research in a vacuum. Refereed Paper, Academy of International Business (AIB) 2016 Conference, 28 June, New Orleans, Louisiana, USA.

Arp, F., and Ardisa, A. (2016b). Effectiveness of microcredit for poverty alleviation: Evidence from Indonesia. Workshop on Human Security in the Global South, Institute of Asia and Pacific Studies (IAPS) and Sustainable Development Research Priority Area (RPA) at University of Nottingham, 24-25 February, Ningbo, China.

Banerjee, A., Breza, E., Duflo, E., and Kinnan, C. (2015). Do credit constraints limit entrepreneurship? Heterogeneity in the returns to microfinance. Working Paper, Northwestern University, Chicago, IL, USA. http://faculty.wcas.northwestern.edu/ cgk281/ credit_entrepreneurship.pdf.

Bank_Rakyat_Indonesia. (2015a). Bank Rakyat Indonesia Annual Report 2014. Bank Rakyat Indonesia (BRI). http://www.bri.co.id.

Bank_Rakyat_Indonesia. (2015b). Kredit Usaha Rakyat BRI. Bank Rakyat Indonesia. http://www.bri.co.id.

Bank_Rakyat_Indonesia. (2016). Bank Rakyat Indonesia Annual Report 2015. Jakarta: Bank Rakyat Indonesia (BRI). http://bri.co.id.

Bos, J. W. B., and Millone, M. (2015). Practice What You Preach: Microfinance Business Models and Operational Efficiency. World Development, 70, $28-42$.

Bruton, G. D., Ketchen, D. J. and Ireland, R. D. (2013). Entrepreneurship as a solution to poverty. Journal of Business Venturing, 28(6), 683-689.

Bruton, G. D., Khavul, S. and Chavez, H. (2011). Microlending in emerging economies: Building a new line of inquiry from the ground up. Journal of International Business Studies, 42(5), 718-739.

Chamberlin, E. H. (1947). The theory of monopolistic competition: a re-orientation of the theory of value (5th ed.). Cambridge, MA: Harvard University Press. 
Chliova, M., Brinckmann, J., and Rosenbusch, N. (2015). Is microcredit a blessing for the poor? A meta-analysis examining development outcomes and contextual considerations. Journal of Business Venturing, 30(3), 467-487.

Citibank. (2016). Enabling financial inclusion through micro-businesses. CITI Global Citizenship Report 2016. http://www.citifoundation.com/citi/about/citizenship/.

Corbin, J. M., and Strauss, A. L. (2008). Basics of qualitative research: techniques and procedures for developing grounded theory (3rd ed.). Los Angeles: Sage Publications.

Creswell, J. W. (2007). Qualitative inquiry and research design: choosing among five approaches (2nd ed.). Thousand Oaks, CA: Sage Publications.

Davidson, L. (2003). Living outside mental illness: Qualitative studies of recovery in schizophrenia. New York: New York University Press.

Ghazali, S. (2003). Kut (informal rotating credit) in the livelihood strategies of urban households in Penang, Malaysia. Area, 35(2), 183-194.

Gine, X. (2011). Access to capital in rural Thailand: An estimated model of formal vs. informal credit. Journal of Development Economics, 96(1), 16-29.

Islam, A., Nguyen, C., and Smyth, R. (2015). Does microfinance change informal lending in village economies? Evidence from Bangladesh. Journal of Banking and Finance, 50, 141156.

Jones, H. M. (2008). Livelihood diversification and moneylending in a Rajasthan village: what lessons for rural financial services? European Journal of Development Research, 20(3), 507-518.

Khavul, S., Chavez, H., and Bruton, G. D. (2013). When institutional change outruns the change agent: The contested terrain of entrepreneurial microfinance for those in poverty. Journal of Business Venturing, 28(1), 30-50.

Kiva.org. (2016). About us. https://www.kiva.org/partner-with-us/employee-andcustomerengagement.

Krugman, P. R., Obstfeld, M., and Melitz, M. (2015). International economics: theory and policy. (P. R. Krugman, M. Obstfeld and M. Melitz, eds.) (9th ed.). Pearson Higher Education.

Mars. (2015). Mars Chocolate: Women's Empowerment Plan. http://www.mars.com/global.

Nghiem, S., Coelli, T., and Rao, P. (2012). Assessing the welfare effects of microfinance in Vietnam: empirical results from a quasi-experimental survey. Journal of Development Studies, 48(5), 619-632.

Pitt, M. M. (2014). Response to "The impact of microcredit on the poor in Bangladesh: revisiting the evidence". Journal of Development Studies, 50(4), 605-610.

Pitt, M. M., and Khandker, S. R. (1998). The impact of group-based credit programs on poor households in Bangladesh: Does the gender of participants matter? Journal of Political Economy, 106(5), 958.

Prasetyo, Y. (2013). How we managed to insure one million people - and what we learned from it. Allianz Life Indonesia April 2013 Microinsurance Case Study Payung Keluarga Credit Life. http://www.allianz.co.id.

Robinson, M. S. (1997). Microfinance in Indonesia. UNESCO Courier, 50(1), 24. 
Roodman, D., and Morduch, J. (2014). The impact of microcredit on the poor in Bangladesh: revisiting the evidence. Journal of Development Studies, 50(4), 583-604.

Sharkey, W. (1982). The theory of natural monopoly. Cambridge, United Kingdom: Cambridge University Press.

Siwale, J. N., and Ritchie, J. (2012). Disclosing the loan officer's role in microfinance development. International Small Business Journal, 30(4), 432-450.

Soursourian, M., Dashi, E., and Dokle, E. (2016). Taking stock: recent trends in international funding for financial inclusion. World Bank Consultative Group to Assist the Poor (CGAP)

2016 Cross-Border Funder Survey, World Bank: Washington, D.C.

Swain, R. B., Nguyen, V. S., and Vo, V. T. (2008). Microfinance and poverty reduction in the Mekong Delta in Vietnam. African and Asian Studies, 7(2/3), 191-215.

Tsai, K. S. (2004). Imperfect substitutes: the local political economy of informal finance and microfinance in rural China and India. World Development, 32(9), 1487-1507.

Turvey, C. G., and Kong, R. (2010). Informal lending amongst friends and relatives: Can microcredit compete in rural China? China Economic Review, 21(4), 544-556.

United Nations. (2017). United Nations Sustainable Development Goals (SDGs). https:// sustainabledevelopment.un.org/topics/sustainabledevelopmentgoals.

United Nations IATF on Financing for Development. (2016). Inaugural 2016 report of the Inter-agency Task Force on Financing for Development - Addis Ababa Action Agenda: monitoring commitments and actions. New York. http://www.un.org/esa/ffd/publications/ inaugural-2016-iatf-report.html.

Usman, A., Kataria, J. R., Awan, H., Hussain, S., and Usman, M. (2015). Elimination of bonded labour in South Asia: the process patronage and labourers' right to access micro credit in brick kiln industry of Pakistan. South Asian Studies (1026-678X), 30(1), 57-66. 
